\title{
The analysis of the sustainable mobility level in selected European cities
}

\author{
Aleksandra Ciastoń-Ciulkin \\ Phd, Eng., Cracow University of Technology, Institute of Construction and Transportation \\ Engineering \& Management, Poland
}

\section{SUMMARY}

Transport needs have to be met through efficient and integrated usage of existing transport infrastructure and urban space together with actions taken in order to reduce traffic congestion by reducing the number and length of travels by car and reducing the demand for the travelling. The expected effect of these actions is the less noise, air pollution and greenhouse gas emissions. The article presents the proposal of the indicator for measuring the degree of sustainable mobility based on the example of European Union cities. The presented method for determining the level of sustainable mobility has been inspired by different researches and it is based on a study of different sub-indicators used for measuring the degree of sustainability of the modal split.

\section{DIFFERENT APPROACHES TO MEASURING SUSTAINABLE MOBILITY}

Due to the increasing negative influence of individual transport, especially in urban areas, the aim is to create sustainable mobility based on the conscious choice of environmentally friendly forms of travelling. The reason for it is that sustainable mobility in cities should fulfill the transport needs of all groups through a proper share of different means of transport in particular areas, and determine the ways of providing transport services in order to minimize their negative environmental and social effects (Ciaston-Ciulkin, 2016). An important element in the shaping of sustainable mobility is establishing and accepting selected and defined progress or regress indices on the way toward achieving it. The systematic determination of those helps observe whether transport behaviors of city dwellers are consistent with the concept of sustainable mobility, as well as what the speed and efficiency of its shaping is. The reference literature comprises different research approaches toward sustainable mobility in urban areas (e.g. Litman, 2015, Miranda, Silva, 2012, Campos, Ramos, Correia 2010). Frequently, among a number of suggestions, one may encounter not only sustainable mobility indices, but also sustainable transport indices. These indices are important from the point of view of mobility because this is the feature that - aside from availability - plays a decisive role in the development of sustainable transport (Borys 2008).

The applied measures of sustainable mobility in cities usually account for economic, 
social, environmental, and mobility-related aspects. These aspects, among others, were taken into consideration in methods of measurement of the development of sustainable transport in Lyon, France (Nicolas, Pochet, Poimboeuf 2003), and Atlanta, Georgia (Jeon, Amekudzi, Guensler 2008). Aspects of mobility usually describe such indices as the number of passengers and cargo, distribution of tasks, traffic congestion, the average distance or speed. Economic and social indices usually include the size of the global cost, as well as individual costs (incurred by the passenger for $1 \mathrm{~km}$ of travel by various means of transport), travel time, access to the transport system, employment in the transport sector, density of vehicles registered, the number of injured or killed in road accidents. Environmental indices usually include energy consumption, air pollution, noise pollution and land use impacts.

An extended, nine-point set of sustainable mobility indices was developed in the Polish city of Wrocław. The key factors, just as in Lyon or Atlanta, were mobility, as well as economic and environmental aspects. Although a group of social factors was not distinguished, indices monitoring the safety of transport were taken into consideration (e.g. the number of car accidents or victims of accidents). Other indicators measuring the degree of sustainable mobility have been classified into groups of factors related to the functioning of various forms of transport, and parking policy. The full set of indicators measuring changes of sustainable mobility creates the list of dozens of positions. The most important of them is the modal split in the city, the average travel time in public transport, the number of casualties in road accidents (mainly pedestrians and cyclists), evaluation of the functioning of the transport system of the city by its users, as well as the state of public awareness for sustainable mobility (2013).

The above examples of sets of indices were designed for particular cities. They would help verify the level of sustainable mobility in other towns to a significant extent; however, at the time of their development, the specificity of a given city was considered, and thus the indices should not be treated as universal. Nevertheless, a set of universal indices was developed by an international team under the leadership of W. Lerner (Lerner 2011). First, the research team suggested a set of eleven indices divided into two groups: the first five of them measured the level of sustainable mobility, and the other six - its effects. The level of sustainable mobility is determined by, among others, the share of eco-friendly transport in the modal split, the sustainable mobility strategy introduced in a given city, the development of car-sharing, the system of city bike rental, as well as the system of smart cards. On the other hand, the effects are determined by safety (the number of people killed in road accidents), carbon dioxide pollution, the motoring index, and an average speed of travel. Then, for each of the indices a bipolar scale was developed, the maximum and minimum values of which were the best and worst indices recorded in the studied 66 cities. Depending on the obtained index, each city received a specific number of points, the sum of which equaled the level of sustainable mobility.

A few years later, another research team proposed a sustainable mobility index expanded to include 19 criteria divided into two groups: maturity and performance (Van Audenhove et al. 2014). In the first group of indices are financial attractiveness of public transport, 
share of public transport in modal split, share of the zero-emission modes in modal split, roads density, cycle path network density, urban agglomeration density, smart card penetration, bike sharing and performance car sharing, public transport frequency and initiatives of the public sector. The second group of factors includes indices of air pollution $\left(\mathrm{CO}_{2}, \mathrm{NO}_{2}\right.$ and PM10), traffic related fatalities, growing share of non-motorized transport in modal split, average travel time to work and density of vehicles registered.

The first and second study conducted helped draw similar conclusions. Although the average values of these mobility indices differ significantly — which is caused by the fact that they arise from different research methodologies - the hierarchy of particular cities is very similar. The developing cities of Asia, Africa, or South America usually struggle with a low level of sustainable mobility. Nevertheless, the effects of activities conducted by highly-developed American cities in terms of sustainable mobility can be considered only average. In those, an intense development of individual transport is observed, whose index of use in urban travel exceeds $80 \%$. The level of sustainable mobility in highly-developed Asian cities does not deviate significantly from the one observed in Northern American cities. In contrast, the most advanced cities in terms of the development of sustainable mobility are situated in Europe. This is the only group whose typical sustainability index is above average. In the group of $15 \%$ of cities with the highest level of sustainable mobility mainly European cities were found ( 7 in 10 in the first study, and 9 in 11 in the second study); at the same time, they were the least represented in the group with the lowest sustainable mobility index. (average of points)

Moreover, the research showed that in all cities, even those recording the highest values of the index, poorly used areas of activity aiming at the shaping of sustainable mobility were found as well. For instance, although in Hong Kong a very advanced system of so-called smart cards is used, the car-sharing system is only being introduced, and the city bike rental system is completely nonexistent. Therefore, one cannot indicate any city as a model with a nearly perfect system of sustainable mobility.

\section{SUSTAINABLE MOBILITY INDEX IN THE EUROPEAN UNION CITIES - OWN RESEARCH}

The abovementioned research inspired the author's own studies in the field of sustainable mobility in the European Union cities. The proposed index is the sum of points obtained from nine partial indices. The indices were divided into three groups related to:

- sustainable transport:

- $\quad$ the share of pedestrian and bike transport in the modal split [\%],

- the share of individual transport in the modal split [\%],

- the effects of sustainable mobility activities:

- $\quad$ traffic congestion index [\%], 
- motoring index (number of passenger cars per 1,000 inhabitants),

- $\quad$ social index (number of people killed in road accidents per 1,000 inhabitants),

- ecology index (PM10 air pollution, annual mean, $\mathrm{ug} / \mathrm{m}^{3}$ ),

- evaluation of the effects of sustainable mobility by the city's inhabitants:

- public transport in the city, for example bus, tram or metro (\% satisfied),

- public spaces such as markets, squares, pedestrian areas (\% satisfied),

- the involvement of the city in the fight against climate change e.g. promoting alternatives to transport by car (\% strongly agree).

For each of the nine partial indices, six ranges of equal span were developed, where the extreme values were the highest and lowest recorded observations in the group of all studied cities. Depending on the range to which the rate of a given index belonged, the studied city was awarded a proper number of points (from 0 to 5). Therefore, the value of the sustainable mobility index illustrates the maximum number of points that a given city received. The research was conducted in 33 European Union cities. The ultimate criterion in the selection of cities for the sustainable mobility research was the availability of considered data. A complete list of partial data and the obtained final index for all 33 cities can be found in the table.

\begin{tabular}{|c|c|c|c|c|c|c|c|c|c|c|c|c|c|}
\hline \multirow[t]{2}{*}{ No } & \multirow[t]{2}{*}{ City } & \multirow[t]{2}{*}{ Country } & 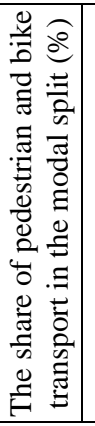 & 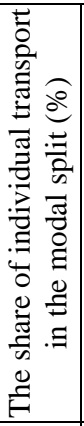 & 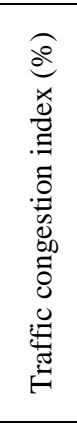 & 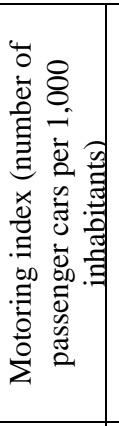 & 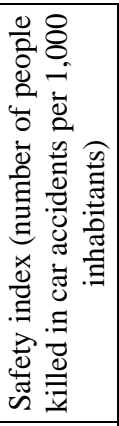 & 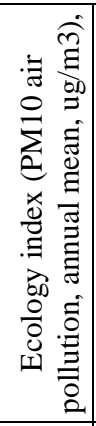 & 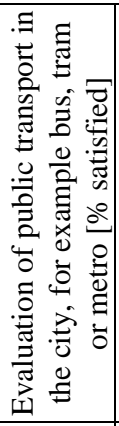 & 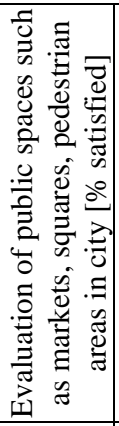 & 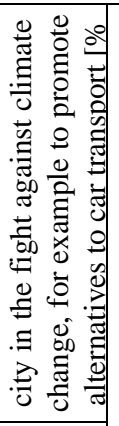 & \multirow[t]{2}{*}{ 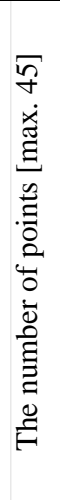 } & \multirow[t]{2}{*}{ 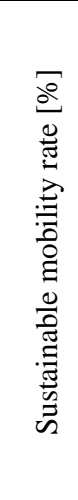 } \\
\hline & & & \multicolumn{2}{|c|}{$2005-2014$} & 2014 & $\begin{array}{l}2009- \\
2013\end{array}$ & $\begin{array}{l}2010- \\
2012\end{array}$ & 2011 & 2012 & 2012 & 2012 & & \\
\hline 1 & Amsterdam & Netherlands & 42 & 38 & 19 & 247 & 0,28 & 24,72 & 80 & 87 & 10 & 40 & 88,89 \\
\hline 2 & Antwerpen & Belgium & 43 & 41 & 28 & 385 & 0,34 & 28,83 & 60 & 82 & 18 & 32 & 71,11 \\
\hline 3 & Barcelona & Spain & 47 & 35 & 27 & 370 & 0,32 & 24,90 & 69 & 83 & 16 & 36 & 80,00 \\
\hline 4 & Berlin & Germany & 43 & 31 & 28 & 289 & 0,16 & 24,48 & 77 & 79 & 9 & 39 & 86,67 \\
\hline 5 & Bordeaux & France & 24 & 67 & 28 & 524 & 0,34 & 24,09 & 83 & 87 & 23 & 29 & 64,44 \\
\hline 6 & Bratislava & Slovakia & 0 & 41 & 23 & 315 & 0,30 & 30,78 & 51 & 64 & 10 & 26 & 57,78 \\
\hline 7 & Bruxelles & Belgium & 5 & 47 & 33 & 451 & 0,22 & 26,52 & 67 & 78 & 18 & 27 & 60,00 \\
\hline 8 & Budapest & Hungary & 20 & 35 & 20 & 328 & 0,19 & 33,24 & 45 & 78 & 11 & 33 & 73,33 \\
\hline 9 & Copenhagen & Denmark & 46 & 33 & 21 & 228 & 0,20 & 12,00 & 77 & 88 & 12 & 41 & 91,11 \\
\hline 10 & Dublin & Ireland & 22 & 57 & 38 & 326 & 0,12 & 17,88 & 70 & 67 & 12 & 29 & 64,44 \\
\hline 11 & Glasgow & UK & 28 & 39 & 24 & 257 & 0,22 & 16,53 & 74 & 76 & 22 & 37 & 82,22 \\
\hline 12 & Hamburg & Germany & 40 & 42 & 32 & 331 & 0,19 & 25,43 & 88 & 87 & 16 & 37 & 82,22 \\
\hline 13 & Helsinki & Finland & 43 & 23 & 22 & 448 & 0,15 & 13,07 & 89 & 86 & 9 & 41 & 91,11 \\
\hline 14 & Cracow & Poland & 26 & 28 & 34 & 485 & 0,36 & 58,82 & 63 & 82 & 7 & 25 & 55,56 \\
\hline 15 & Liège & Belgium & 8 & 76 & 17 & 409 & 0,50 & 25,36 & 64 & 75 & 16 & 25 & 55,56 \\
\hline 16 & Lille & France & 34 & 57 & 21 & 441 & 0,13 & 28,50 & 86 & 80 & 21 & 34 & 75,56 \\
\hline 17 & Lisboa & Portugal & 17 & 48 & 29 & 410 & 0,20 & 27,92 & 62 & 69 & 7 & 29 & 64,44 \\
\hline
\end{tabular}




\begin{tabular}{|c|c|c|c|c|c|c|c|c|c|c|c|c|c|}
\hline 18 & London & UK & 38 & 9 & 37 & 294 & 0,20 & 21,81 & 84 & 79 & 14 & 38 & 84,44 \\
\hline 19 & Luxembourg & Luxembourg & 26 & 60 & 28 & 667 & 0,22 & 18,25 & 79 & 90 & 28 & 30 & 66,67 \\
\hline 20 & Madrid & Spain & 29 & 29 & 21 & 468 & 0,16 & 21,75 & 68 & 68 & 13 & 33 & 73,33 \\
\hline 21 & Malmö & Sweden & 37 & 42 & 16 & 353 & 0,13 & 20,66 & 75 & 91 & 22 & 39 & 86,67 \\
\hline 22 & München & Germany & 42 & 37 & 27 & 351 & 0,13 & 21,19 & 85 & 90 & 20 & 39 & 86,67 \\
\hline 23 & Oslo & Norway & 37 & 37 & 25 & 378 & 0,20 & 22,89 & 84 & 78 & 10 & 37 & 82,22 \\
\hline 24 & Palermo & Italy & 14 & 71 & 42 & 597 & 0,59 & 25,00 & 14 & 39 & 8 & 11 & 24,44 \\
\hline 25 & Paris & France & 50 & 17 & 35 & 234 & 0,19 & 23,60 & 70 & 81 & 14 & 38 & 84,44 \\
\hline 26 & Praha & Czech Rep. & 24 & 33 & 27 & 541 & 0,30 & 26,18 & 78 & 80 & 5 & 31 & 68,89 \\
\hline 27 & Roma & Italy & 21 & 59 & 38 & 698 & 0,66 & 32,09 & 32 & 60 & 12 & 14 & 31,11 \\
\hline 28 & Rotterdam & Netherlands & 34 & 49 & 19 & 318 & 0,29 & 24,98 & 87 & 83 & 13 & 38 & 84,44 \\
\hline 29 & Stockholm & Sweden & 18 & 47 & 30 & 362 & 0,14 & 14,66 & 80 & 83 & 16 & 34 & 75,56 \\
\hline 30 & Strasbourg & France & 41 & 47 & 24 & 447 & 0,26 & 25,11 & 88 & 88 & 23 & 36 & 80,00 \\
\hline 31 & Warsaw & Poland & 22 & 24 & 40 & 580 & 0,40 & 34,68 & 80 & 65 & 3 & 18 & 40,00 \\
\hline 32 & Wien & Austria & 34 & 27 & 29 & 390 & 0,19 & 27,27 & 88 & 88 & 17 & 38 & 84,44 \\
\hline 33 & Zürich & Switzerland & 41 & 30 & 30 & 365 & 0,16 & 20,26 & 95 & 86 & 28 & 38 & 84,44 \\
\hline \multicolumn{3}{|c|}{ Average } & 30 & 41 & 28 & 402,64 & 0,26 & 24,95 & 72 & 79 & 15 & 32 & 72,19 \\
\hline
\end{tabular}

\section{Table 1 - Nine partial indices in European Union cities}

The higher the share of pedestrian and bike travel and, simultaneously, the higher the share of public transport in motorized travel, as well as the lower the motoring index, the number of traffic fatalities, and PM10 pollution, the higher the sustainable mobility index. The hierarchy of all the analyzed cities is shown in Figure 1.

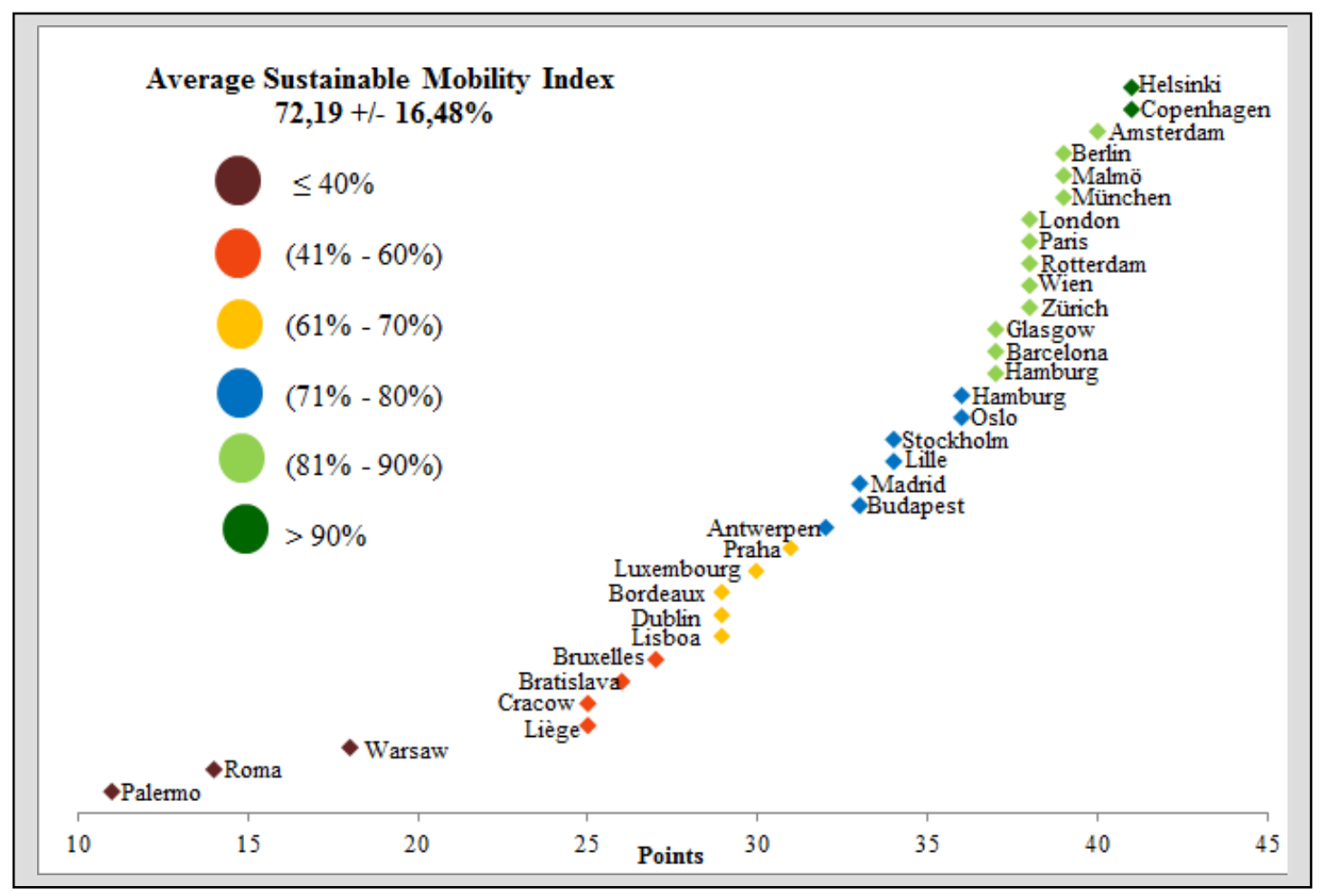

Fig. 1 - The Average Sustainable Mobility Index in the European Union cities

Synthetically, the sustainable mobility index for all 33 cities amounts to $72 \%$, as they 
received 32 out of 45 achievable points on average. The most points were awarded to Scandinavian, German-speaking, and British cities. This group also included Paris and Barcelona. The lowest results in terms of all studied aspects were achieved by Italian and Polish cities. Below average, there were also Brussels, Geneva, and Bordeaux.

Cities shaping sustainable mobility should be considered those in which, among others, a low motoring index is observed. The factor that would illustrate the state of sustainable mobility in cities even more effectively should be the progress of its changes, the proper direction being a drop in the motoring index over time. This assumption is all the more justified that a declining interest in owning a car does not result directly from the costs of its purchase or use, but rather from the changing transport behaviors and the growing awareness of the social and ecological costs of congestion. It is confirmed by, among others, the negative correlation between the rate of growth of the number of cars in the city, and the rate of gross domestic product per capita.

The declining interest in individual transport is characteristic of German cities, in which a constant decline in the motoring index has been observed since 2005, as compared with the average annual increase of about $1 \%$ in the number of cars across the country. In the years 2006-2011, the motoring index in German cities fell by about 10-18\% (Eurostat). The largest decline in the number of cars was recorded in Munich (18\%), Hamburg (16\%), and Stuttgart $(15 \%)$. In the capital city the motoring index fell only by $10 \%$; however, one should note that in Berlin one of the lowest motoring indices in large European cities is recorded.

Tangible effects in the form of the declining motoring index are achieved also in other large Western European cities. According to Eurostat, in the years 2007-2011, an average $5 \%$ decline in the number of passenger cars was recorded in Brussels, Paris, or Rotterdam. Amsterdam, in which the number of passenger cars in an analogous period of time was reduced by $11 \%$, is also of interest; one should mention that in this Dutch city as early as in 2006, there were about three bikes for every passenger car - about 0.75 bike per inhabitant (Buehler, Pucher, 2010).

A greater interest in owning a car is usually expressed by less affluent societies of Central and Eastern Europe, to which the car is a symbol of prestige and luxury. For instance, in Poland the number of passenger cars increased by an average of $63 \%$ in a decade (20022011). Individual transport is of equal importance only in Italian cities, in which the motoring index often exceeds 500 vehicles per 1,000 inhabitants. The situation is similar in Luxembourg, Prague, and Bordeaux.

Non-motorized transport (pedestrian and bike travel) plays an important role in Western European cities, including ones inhabited by more than 1,000,000 people. Pedestrian and bike travel often oscillates between 30 and $40 \%$ of the share in all travel and is twice as frequent as in Central and Eastern European cities. This is the case for Barcelona (47\%), Belin (43\%), Munich (42\%), Hamburg (40\%), London (38\%), or Lille (34\%), among others. Here, also Paris is of special interest, as in this city in 2008 pedestrian and bike 
transport had as much as half the share in urban transport. Moreover, pedestrian and bike travel is often encountered in Scandinavian cities.

Public transport takes priority over individual transport mainly in the largest European Union cities: London, Madrid, and Paris. The advantage is associated with intense activities affecting changes in the transport behaviors of users of individual transport. For instance, systematic and wide-ranging activities in the years 2002-2008 contributed to nearly a three-time reduction in the share of this means of transport in urban travel in Paris. On the other hand, the share of public transport nearly doubled, and the people of Paris began to travel on foot about 50\% more often. For years, in Paris and the Paris metropolitan area, the organizer of STIF transport has been analyzing transport behaviors in detail in order to adjust the provided services to the actual flow of passengers. The STIF has also tried to adapt the offer of public transport to changes in the lifestyle of the inhabitants by means of an increased offer outside of rush hours (evenings, nights, weekends, the holiday season). Moreover, public transport is financed not only by ticket sales $(30 \%)$ but also by so-called transport tax paid by Ile-de-France companies employing nine or more people $(8 \%)$, and by refinancing privilege tickets $(9 \%)$. Moreover, the Paris metropolitan area is investing heavily in the development of infrastructure dedicated to eco-friendly transport (expansion of the subway, urban railway, tramways, bus network development, intermodal hubs, preferential treatment in traffic for public transport vehicles, car- and bike-sharing systems, etc.). A share of public transport larger than that of individual transport is recorded also in some Central and Eastern European cities. However, in their case, this advantage is gradually decreasing as a result of the rapid increase in the number of passenger cars.

Little interest in travel by car expressed by people inhabiting Western European cities translates into a low social index - the least people are killed in road accidents in the aforementioned cities with a high share of eco-friendly transport, including Paris and Copenhagen, as well as in the studied Scandinavian or German-speaking cities. The group of cities in which the rate of fatalities is the highest comprises those with the highest motoring indices and shares of individual transport, such as Luxembourg, Rome, Palermo, as well as Warsaw.

\section{CONCLUSION}

An undeniably high sustainable mobility index is found mainly in cities in which a wide range of instruments affecting a change in previous transport behaviors aiming to introduce eco-friendly means of transport are applied in practice. This group comprises mainly Western European cities. Central and Eastern European cities, on the other hand, demonstrate the development of a pro-car culture, visible in a steady increase in the number of privately-owned vehicles. However, their advantage is the still large share of public transport in urban travel. The task that the cities should undertake now is one of 
effectively shaping their transport behaviors aiming for sustainable mobility and of preventing a further increase in individual transport.

\section{REFERENCES}

AUDENHOVE F.J., KOMIICHUK O., DAUBY L. POURBAIX J. The Future of Urban Mobility 2.0, Imperatives to shape extended mobility ecosystems of tomorrow, Arthur D Little Global CEO, 2014.

BORYS T. Analiza istniejacych danych statystycznych pod katem ich użyteczności dla określenia poziomu zrównoważonego transportu wraz z propozycja ich rozszerzenia, Raport z realizacji pracy badawczej, Ministerstwo Infrastruktury, Warszawa 2008.

BUECHLER R., PUCHER J. (2010) Cycling to Sustainability in Amsterdam, Sustain, A journal of environmental and sustainability issues, Issue 21, pp. 36-40.

CAMPOS V.B.G, RAMOS R.A.R., CORREIA S. (2009). Multi-criteria analysis for sustainable mobility evaluation in urban areas, Journal of Advanced Transportation 43(4), pp. 371-390.

CIASTON-CIULKIN A. (2014) Zrównoważona mobilność mieszkańców obszarów zurbanizowanych, Autobusy. Technika, Eksploatacja, Systemy Transportowe 11, pp. 14-20. FREITAS MIRANDA H., SILVA A.N.R. (2012). Benchmarking sustainable urban mobility: The case of Curitiba, Brazil, Transport Policy 21, pp. 141-151.

JEON Ch.M, AMEKUDZI A.A., GUENSLER R.L. (2013) Sustainability Assessment at the Transportation Planning Level: Performance measures and indexes, Transport Policy 25, pp. 10-21.

LERNER W. The Future of Urban Mobility, Towards networked, multimodal cities of 2050, Arthur D Little future lab, No.1: Future of Urban Mobility, 2011.

LITMAN T. Well Masured. Developing Indicators for Sustainable and Livable Transport Planning, Victoria Transport Policy Institute, 2015.

MOUGARD S. (2012) STIF: An Integrated Public Transport Authority to Meet the Challenges of Mobility, Public Transport International 61(1), pp. 8-10.

NICOLAS J.P., POCHET P., POIMBOEUF H. (2003) Towards Sustainable Mobility Indicators: Application To The Lyons Conurbation, Transport Policy 10(3), pp. 197-208.

STEG L., GIFFORD R. (2005) Sustainable transportation and quality of life, Journal of Transport Geography 13(1), pp. 59-69.

WROCŁAWSKA POLITYKA MOBILNOŚCI. Załącznik do Uchwały No. XLVIII/1169/13 Urząd Miasta Krakowa, 2013. 